\title{
Aerodrome Warning Verification Using Quality Measurement of Contingency Table (Case Study in Jakarta and Tanjungpinang)
}

\author{
Mochammad Donny Anggoro ${ }^{1}$, Diana Cahaya Siregar $^{2}$, Regina Dara Ninggar ${ }^{3}$, Laksita \\ Widomurti $^{4}$ \\ \{donny.bmkg@gmail.com ${ }^{1}$, siregardianacahaya@gmail.com ${ }^{2}$, \\ regibuzz@gmail.com ${ }^{3}$, laksitamurti@gmail.com ${ }^{4}$ \} \\ Soekarno-Hatta Meteorological Station, Banten, 15126, Indonesia ${ }^{1}$, \\ Tanjungpinang Meteorological Station, Riau Islands, 29125, Indonesia ${ }^{2}$ \\ Meteorological, Climatological, and Geophysics Agency Region II South Tangerang, Banten, 15411, \\ Indonesia $^{3}$ \\ Sultan M. Salahuddin Bima Meteorological Station, NTB, 84173, Indonesia $^{4}$
}

\begin{abstract}
Improvement in Aerodrome Warning (AW) nowcasts need better prediction for supporting the safety and security of air traffic from extreme weather. AW consists of weather conditions, wind direction and wind speed, and visibility with observing time and validity time of forecast. Weather forecast verification is important for all stakeholders in the airport, so they can prepare and have plans to mitigate undesirable activity disturbance. AW and Automated Weather Observing System (AWOS) data are from Soekarno-Hatta Meteorological Station (07L) and Tanjungpinang Meteorological Station for January to April2019. Statistic test using hits, false alarm, misses, the correct negative is to find the score of POD, Bias, FAR, TS, and HSS which is to measure the magnitude of AW. Overall, AW has good accuracy to predict the extreme weather in the aerodrome.
\end{abstract}

Keywords: Aerodrome Warning, AWOS, Weather Forecast

\section{Introduction}

Aviation meteorology is the most important aspect of supporting the safety and security of air traffic from extreme weather [1]. Weather conditions can cause or contribute to the aviation accidents included wind, visibility or ceiling, high-density altitude, turbulence, carburetor icing, updrafts or downdrafts, precipitation, icing, thunderstorms, wind shear, thermal lift, temperature ( $\mathrm{T}$ ) extremes, and lightning [2]. A weather forecaster is an actor who guarantees the efficiency and effectiveness of airport operational without affected by weather, so they have to observe all the weather parameters such as air temperature, winds, weather condition, and visibility. Furthermore, these parameters are analyzed in an isobar chart, streamline chart, and upper air chart to get an accurate weather forecast.

Based on Figure 1, accidents by flight phase as a percentage of all accidents from 1998 to 2017 have dominantly occurred with approach (up to 20\%) and landing (up to 50\%). Next, it was followed by parking and taxi as a non-fatal hull loss, but it was also essential. Building and cargo in aerodrome may be received damage from the weather such as floods or strong 
surface winds. To minimize the negative risks, World Meteorological Organization (WMO) has arranged the rules with the use of Aerodrome Warning in Technical Regulations [4], Volume II, Part I, 7.3. In Indonesia, The Agency for MeteorologyClimatology and Geophysics (BMKG) also compiled the detailed of Aerodrome Warning in PERKA BMKG No. 13 Tahun 2015 [5]. Aerodrome Warning is concise information about meteorological conditions that can affect aircraft and airport service facilities on land such as runway.

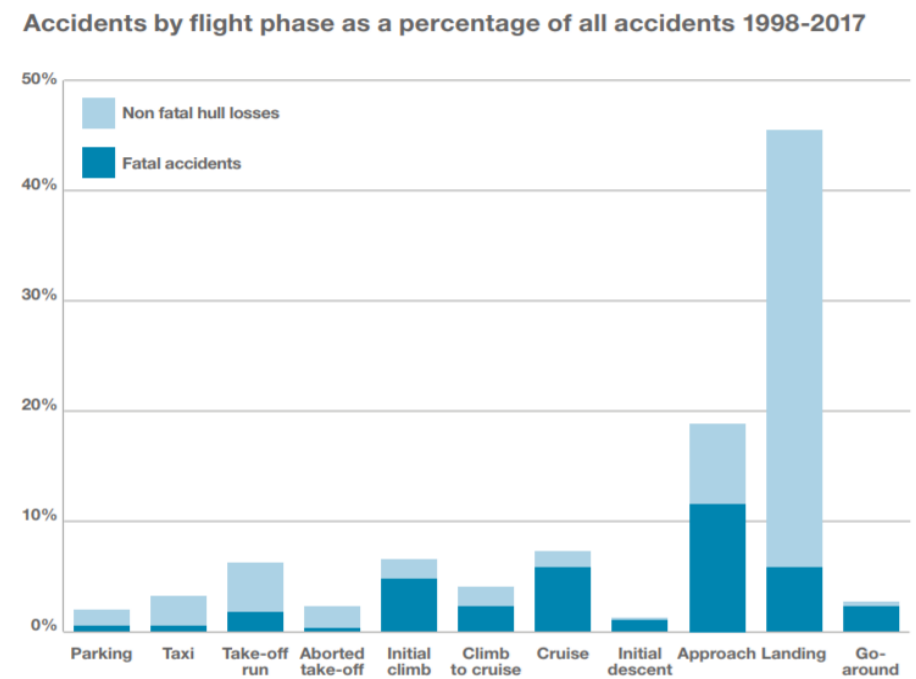

Fig. 1. Percentage of all flight phase accidents 1998-2017 [3]

Aerodrome Warning (AW) consists of weather conditions, wind direction and wind speed, and visibility with observing time and validity time of forecast. Weather conditions as though rainfall, tropical cyclones, thunderstorm, squall, hail, fog, volcanic ash, tsunami, smoke, and toxic chemistry gases should be reported if it occurred or will occur in AW format. Delay avoiding, cargo activities will be fluent and aircraft parking will exists in safety cone and remains sterile if AW is disseminated well [6].

\section{WIII AD WRNG 02 VALID 170420/170530 HVY TSRA WIND 28015KT MAX 25KT OBSAT $170400 \mathrm{NC}=$}

The code form above explains about Aerodrome Warning in Soekarno-Hatta Meteorological Station (WIII) number 2 with time validity on date 17 from 04:20 UTC until 05:30 UTC will occur heavy rain with thunderstorm with the average wind direction is from $280^{\circ}$ (South-West) and wind speed is $15 \mathrm{knot}$, and maximum wind speed up to 25 knot. The observation of AW was 04:00 UTC on date 17, with no change of phenomena intensity.

Improvement in aerodrome warnings nowcasts need better predictions, thus a verification becomes its measurement. Weather forecast verification provides benefits, such as knowing the mistake which causes false prediction [7]. In cases, all stakeholders in the airport can prepare and have plans to mitigate undesirable activity disturbance. 


\section{Materials}

Aerodrome warning archives from January to April 2019 are needed as the basic materials. A computer, an especially calculator, are used to calculate all formula in statistic verification. Automatic Weather Observation System (AWOS) data from January to April 2019 are collected in one folder including rainfall events, thunderstorm events, the peak of wind speed, and minimum visibility. Aerodrome warning and AWOS data are from SoekarnoHatta Meteorological Station (07L) and Tanjungpinang Meteorological Station.

Table 1. Meteorological stations coordinate

\begin{tabular}{|c|c|c|c|}
\hline No. & Location References & Latitude & Longitude \\
\hline 1. & Soekarno-Hatta Meteorological Station & $06^{0} \quad 7.53^{\prime} \mathrm{LS}$ & $106^{0} \quad 39.35^{\prime} \mathrm{BT}$ \\
\hline 2. & Tanjungpinang Meteorological Station & $00^{0} \quad 55^{\prime} \mathrm{LU}$ & $104^{0} \quad 31.8^{\prime} \mathrm{BT}$ \\
\hline
\end{tabular}

\section{Methods}

Aerodrome warning as a nowcasting forecast and AWOS data as observation references are verified into 5 statistic parameters, such as Probability of Detection (POD), Bias, False Alarm Ratio (FAR), Threat Score (TS), and Heidke Skill Score (HSS).

Table 2. Contingency table

\begin{tabular}{cccc}
\cline { 3 - 4 } & & \multicolumn{2}{c}{ Observation } \\
\cline { 3 - 4 } & & Yes & No \\
\hline \multirow{2}{*}{ Prediction } & Yes & Hits & False Alarms \\
& No & Misses & Correct Negatives \\
\hline
\end{tabular}

Value of Hits, False Alarms, Misses, and Correct Negatives be required for calculating those 5 parameters. Hits means the prediction and the observation occurred simultaneously, besides Correct Negatives means both of them do not occur. False Alarms shows that the forecast said "Yes", but in observation, it does not occur. Misses means that there is no prediction, but there happened extreme weather that passes the threshold.

$$
\begin{aligned}
& \text { POD }=\frac{\text { Hits }}{\text { Hits }+ \text { Misses }} \\
& \text { FAR }=\frac{\text { False Alarms }}{\text { Hits +False Alarms }} \\
& \text { BIAS }=\frac{\text { Hits +False Alarms }}{\text { Hits +Misses }} \\
& \mathrm{TS}=\frac{\text { Hits }}{\text { Hits +False Alarms +Misses }}
\end{aligned}
$$

Probability events that can be detected by the Probability of detection (POD), is part of the incident what was observed occurred ("yes") and predicted. The value between 0 and 1 , 
the best value when POD equals 1 . The number of events predicted will occur ("yes"), but it does not occur as indicated by False Alarm Ratio (FAR). The value is between 0 and 1 which FAR equals 0 is the best value.

Bias is a comparison of the average forecast towards the average observation and shows the frequency of a forecast event compared to observed events. Bias value can show how is the relationship between predictions occurring "yes" with "yes" observations, can be obtained by equation (1). The value is between 0 and $\infty$, with bias equals 1 , is the best value. Threat score (TS) can show a comparison predictions of the occurrence of "yes" with observations of events "yes", TS values range from 0 and 1, 0 indicates predictions without skill and 1 for the best predictions.

$$
\begin{gathered}
\text { HSS }=\frac{(\text { Hits }+ \text { Correct Negatives })-(\text { Expected Correct })_{\text {random }}}{\mathrm{N}-(\text { Expected Correct })_{\text {random }}} \\
\text { where } \\
(\text { Expected Correct })_{\text {random }}=\frac{(\text { Misses })(\text { Hits }+ \text { False Alarms })+}{\text { (Correct Negatives }+ \text { Misses })(\text { Correct Negative }+ \text { False Alarms })} \\
\text { Total }
\end{gathered}
$$

Verification will also be used Hiedke Skill Score (HSS) which can provide relative accuracy of forecasts against the chance of random. The HSS value interval is $-\infty$ to 1 . Value 1 shows the perfect forecasts.

Mean Absolute Error (MAE) measures the average magnitude of the errors in a set of forecasts, without considering their direction. It measures accuracy for continuous variables. Expressed in words, the MAE is the average over the verification sample of the absolute values of the differences between forecast and the corresponding observation. MAE is a linear score which means that all the individual differences are weighted equally in the average.

Root Mean Squared Error (RMSE) measures the average magnitude of the error. The difference between forecast and corresponding observed values are each squared and then averaged over the sample. Finally, the square root of the average is taken. Since the errors are squared before they are averaged, the RMSE gives a relatively high weight to large errors. This means RMSE is the most useful when large errors are particularly undesirable. MAE and RMSE can be used together to diagnose the variation in the errors in a set of forecasts. RMSE will always be larger or equal to MAE which there isthe difference between them especially for thevariance in the individual errors in the sample. If RMSE is similar to MAE, then all the errors are of the same magnitude. Both the MAE and RMSE can range from 0 to $\infty$. They are negatively-oriented scores which are lower values are better.

\section{Results and Discussion}

\section{a. Tanjungpinang Meteorological Station}

Rainfall variability in the Tanjungpinang was influenced by many factors. Weather patterns in Tanjungpinang were affected by its geographical location which was surrounded by the ocean so that the convection that occurs was more influenced by local factors [8]. Climatologically, it will go through wet conditions which were the precipitation that occurs quite frequently from November to January and went through dry conditions with little 
precipitation in February. The Agency for Meteorology Climatology and Geophysics (BMKG) was intensively socialize the making of aerodrome warnings as a basis for early warning for extreme weather events such as heavy rain, low visibility, and strong winds which may occur around the runway or airport. BMKGled Tanjungpinang Meteorological Station to make an aerodrome warning for extreme weather conditions at Raja Haji Fisabilillah International Airport. Precipitation forecasting was one of the difficult parts to predict and was still being studied [9]. It could be done subjectively based on the forecaster point of view and objective by using a statistical or numerical methods.

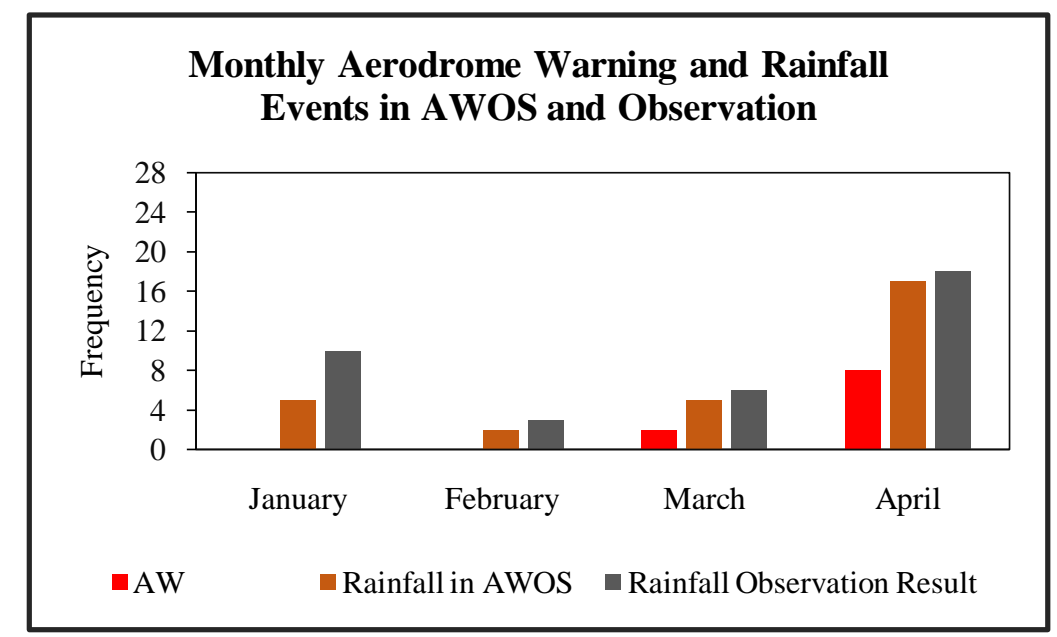

Fig. 2. Frequency chart of aerodrome warning toward rain events reported on AWOS or manual observation

Figure 2 interpreted the aerodrome frequency warning chart produced bythe forecaster of Tanjungpinang Meteorological Station for extreme weather that occurred at the runway of Raja Haji Fisabilillah International Airport. It showed that aerodrome warning issued not routinely given when there was the potential for extreme weatherespecially when rain has occurred, which could affect the safety of airplane operation. Aerodrome warning for January and February was not made by forecasters of Tanjungpinang Meteorological Station during rain event that observed by AWOS or manual observation. Precipitation intensity that occurred in JanuaryandFebruary was mostly in the light intensity where some rainfall events were measured in rain gauge or AWOS as a trace of rain or no measurable accumulation.

Table 3. Contingency table for aerodrome warning verification

\begin{tabular}{cccccc}
\hline & POD & BIAS & FAR & TS & HSS \\
\hline January & 0 & 0 & 0 & 0 & 0 \\
February & 0 & 0 & 0 & 0 & 0 \\
March & 0.40 & 0.40 & 0 & 0.40 & 0.18 \\
April & 0.44 & 0.44 & 0 & 0.44 & 0.08 \\
\hline
\end{tabular}

Rainfall frequency observed by AWOS in March and April also did not record actual rainfall events or measure it as a trace of rain (about 8.33\%) a couple of times, but the rainfall 
frequency was smaller compared for January and February(about 53.84\%). The frequency of aerodrome warnings in March and April ranged about $41.67 \%$ from the occurrence of rain events. It happened because of the rain that occurred is only in light category so the aerodrome warning was not made and disseminated to related parties.

Table 4. Contingency table of aerodrome warning verification issued during extreme weather

\begin{tabular}{ccccc}
\hline & Hits & False Alarm & Missed & Correct Negative \\
\hline March & 0.75 & 0.25 & 0 & 0 \\
April & 0.52 & 0.48 & 0 & 0 \\
\hline
\end{tabular}

Aerodrome warning was verified by using the accuracy of statistical value predictions. The parameter values used to verify aerodrome warning issued by the Tanjungpinang Meteorological Station were presented in Table 3. Aerodrome warning issued from March to April2019 was verified to find out the accuracy of the actual forecast towards extreme weather events recorded by AWOS. Verification was assessed only when aerodrome warning was issued and extreme weather conditions occurred, especially for the rainfall with light to heavy intensity followed by the potential for strong wind and thunderstorm. As for the dates which became the focus of verification in March 2019 that is 28 and 30 as well as in April 2019 that is on $10,11,12,14,20,26,29$, and 30 . The results of verification were presented in Table 4 .

\section{b. Soekarno-Hatta Meteorological Station}

Soekarno-Hatta Meteorological Station has been as a unit that disseminated Aerodrome Warning in Soekarno-Hatta International Airportincluded for 2 runways (07R/25L and 07L/25R) and has added a challenge to cover new runway (06/24). Figure 3 showed that in January and February, there were quite differences counted which recorded in Automatic Weather Observing System (AWOS) and Hellmann rain gauge paper as observation results. It was caused by rainfall pattern that enters to the aerodrome in other points of the runway.

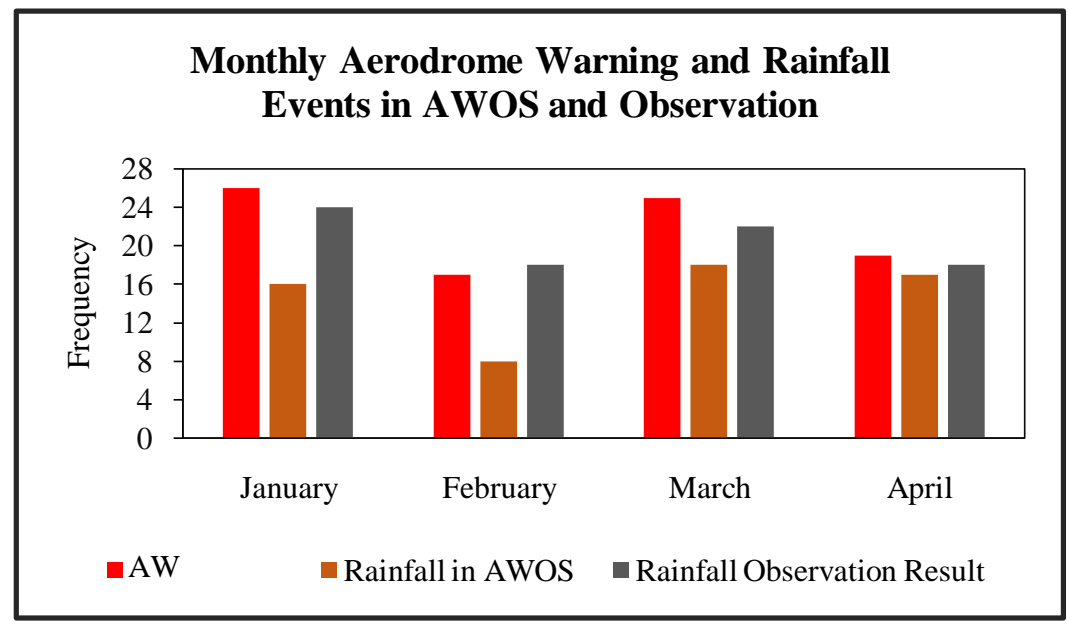

Fig. 3. Frequency chart of aerodrome warning toward rain events reported on AWOSor manual observation 
Table 5. Contingency table of aerodrome warning verification

\begin{tabular}{cccccc}
\hline & POD & BIAS & FAR & TS & HSS \\
\hline January & 0.69 & 0.88 & 0.21 & 0.58 & 0.47 \\
February & 0.75 & 1.12 & 0.33 & 0.54 & 0.54 \\
March & 0.94 & 1.31 & 0.29 & 0.68 & 0.52 \\
April & 0.78 & 1.22 & 0.36 & 0.54 & 0.54 \\
\hline
\end{tabular}

Furthermore, wind direction and speed was as the main factor of those conditions. 07L point in North runway would be touched if the wind moved from West. Figure 3also interpreted the highest number of aerodrome warning production was in January.Table 5 above indicated that the best score of POD was in Marchand also became the highest Bias value. FAR and TS amount among 4 months were not in big difference and they showed a good prediction. For HSS, it was still around fifty percent that meant the forecast was still in a good based on forecast relative accuracy. However, Soekarno-Hatta Meteorological Station in 4 months above was in critical season that was the rainy season. By analyzing all the values in Table 5, weather forecasters in Soekarno-Hatta Meteorological Station were capable to provide Aerodrome Warning.

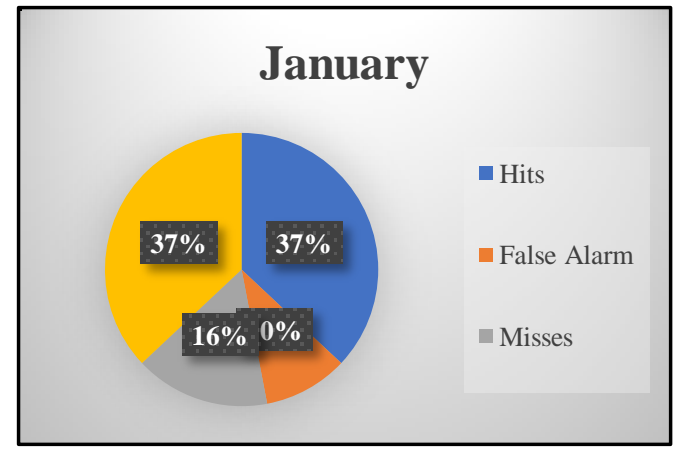

(a)

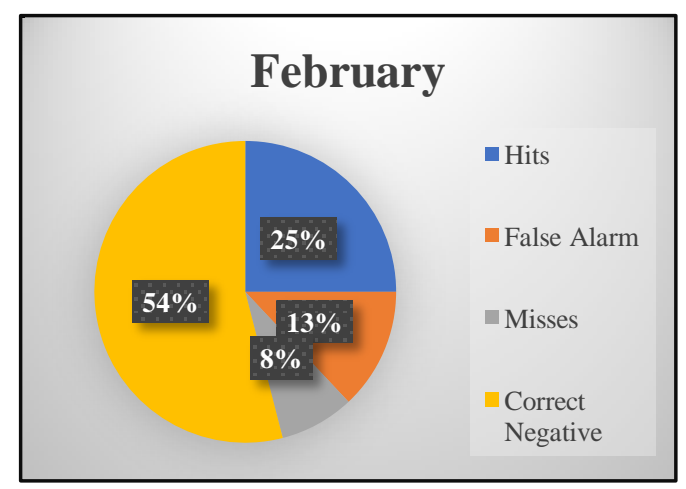

(b)

Fig. 4. Distribution of contingency parameters as basic calculation in January (a) and February (b) 
January and February as the peak of the rainy season were needed to minimize False Alarm prediction. Figure 4 illustrated that most of the Hits and Correct Negative were dominating in all data. The bad result of prediction for misses in January was two times higher than February. False Alarm in February was still bigger.To more detail, March exists as the biggest amount of False Alarm (Figure 5). But, Hits number was also in the biggest one. It meant that a weather forecaster wouldbe difficult to predict the time of rainfall occurrence in a transition season.

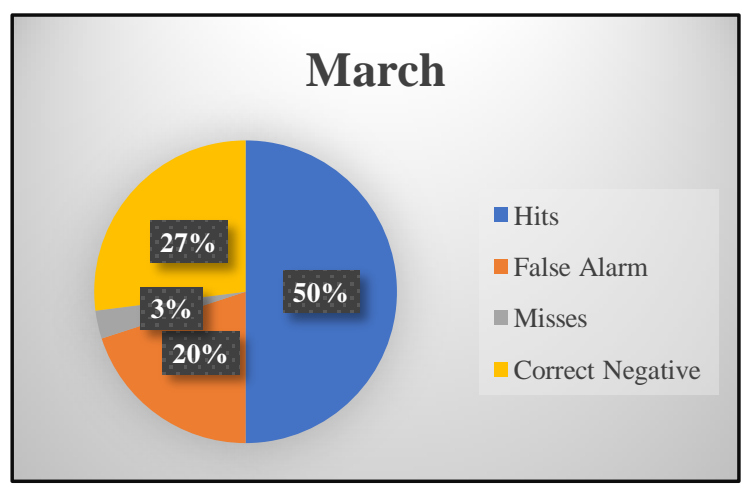

(a)

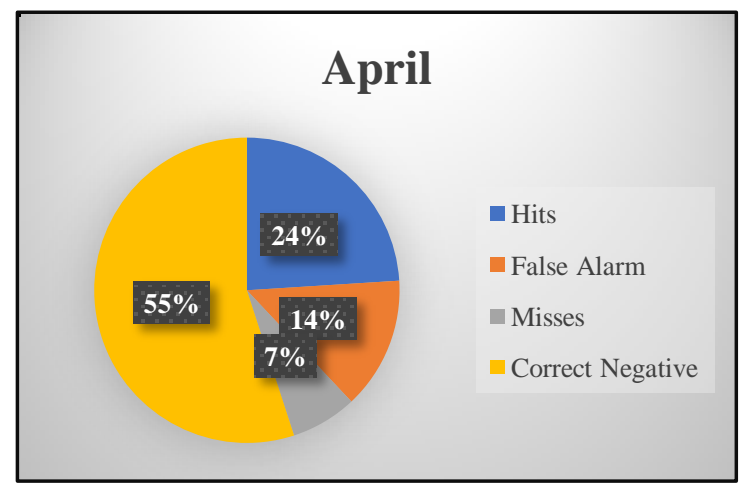

(b)

Fig. 5. Distribution of contingency parameters as the basic calculation in March (a) and April (b)

Figure 6showed the number of Aerodrome Warning (AW) issued for wind parameters and visibility. The warning given was in the form of information on increasing wind speed significantly and visibility reduction which could affect aircraft operation. March was a month with the highest number of AW issued for both wind and visibility parameters, while February was a month with the lowest number of AW issued for wind parameters and visibility.

Table 6showed the AW verification value issued by comparing AWOS data. Verification for wind and visibility parameters was done by statistical methods, namely MAE and RMSE. Verification was carried out in the AW issued from January to April2019. The verification value would be a good value if MAE and RMSE values were close to zero, so AW was able to 
predict extreme weather. Table 6 showed that AW could predict theextreme events specifically wind and visibility parameters. However, AW for wind parameter that issued in February 2019 was not able to predict correctly and showed a large verification value.

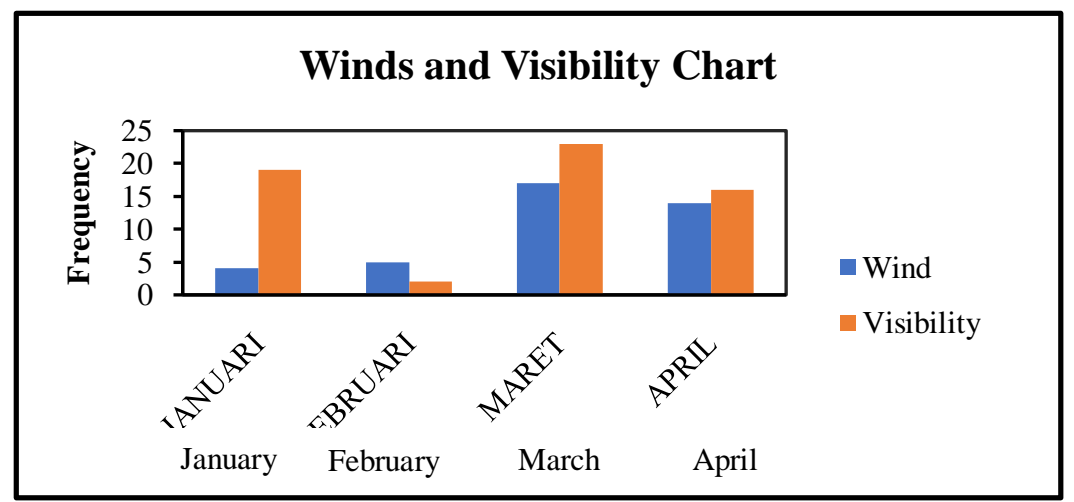

Fig. 6. Frequency of AW production on wind and visibility parameters

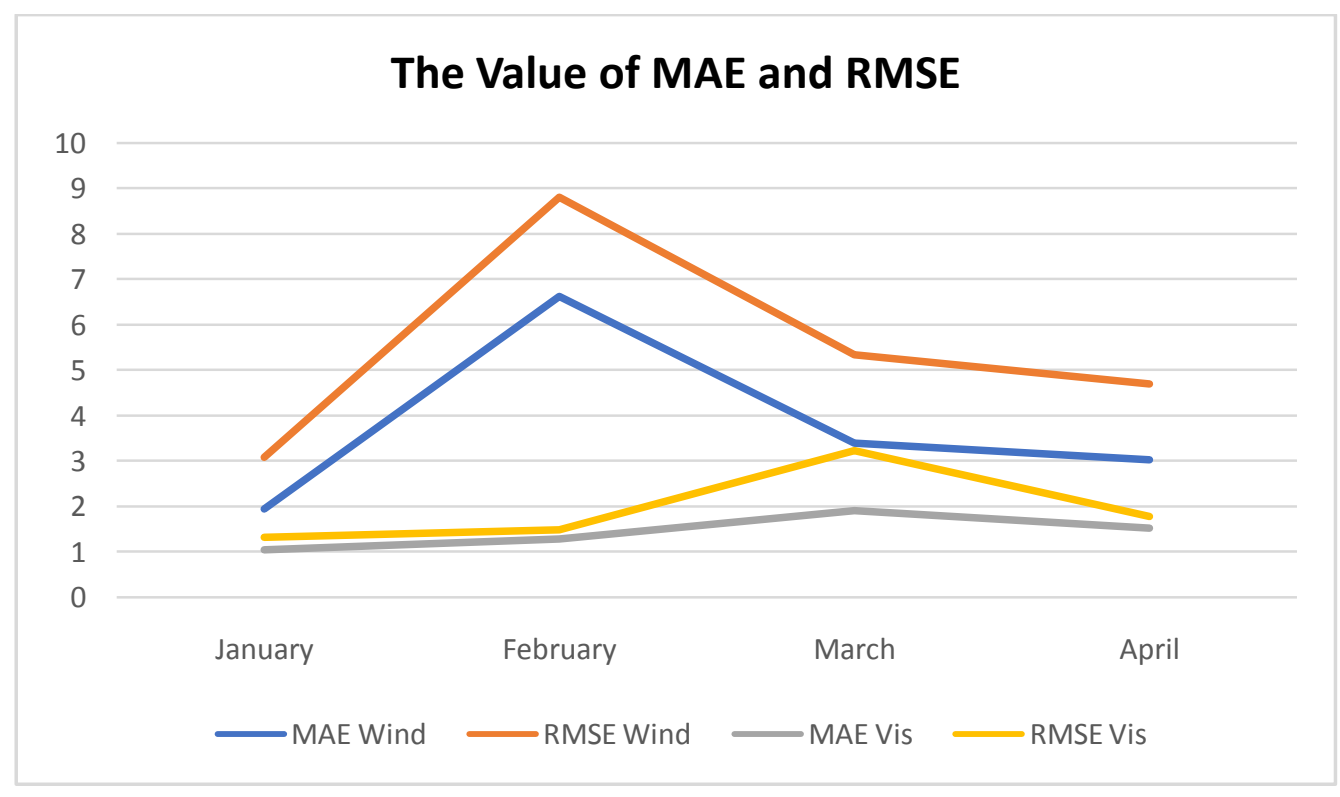

Fig. 7.The value of MAE and RMSE between wind and visibility

By analyzing the contingency table, the verification results showed that Aerodrome Warning in Tanjungpinang Meteorological Station and Soekarno-Hatta Meteorological Station were quite good. The research would be better and more valid by increasing temporal data amounts and inclining weather parameters. 


\section{References}

[1] Gultepe, I., Sharman, R., Williams, P. D., Zhou, B., Ellrod, G., Minnis, P., Neto, A.: A Review of High Impact Weather for Aviation Meteorology. Pure and Applied Geophysics. pp. 1 (2019)

[2] NTSB: NASDAC Review of National Transportation Safety Board (NTSB) weather-related accidents (2003-2007). http://www.asias.faagov/ (2010)

[3] Airbus: A Statistical Analysis of Commercial Aviation Accidents 1958-2017. Issue 2. May 2018. pp. 22 (2018)

[4] WMO: Meteorological Service for International Air Navigation: 2013 Edition. Technical Regulations WMO Volume II, pp. 24 (2013)

[5] BMKG: PERKA BMKG No. 13 Tahun 2015 tentang Tata Cara Tetap Pelaksanaan Pembuatan, Penyampaian, Penyebaran, Pembatalan, dan Pengakhiran Wind Shear Warning dan Aerodrome Warning (2015)

[6]Hough, S.: IATA Safety Report 2018. April 2019, pp. 3 (2019)

[7]Ramage, C. S.: Forecasting in Meteorology. Bull. Amer. Meteor. Soc. 1863-1871. pp. 74 (1993)

[8]Siregar, D. C., Anugrah, R. A. and Tumardi: Simulasi prediksi total hujan bulanan di tanjungpinang (studi kasus tahun 2017). Jurnal Statistika dan Aplikasinya, pp. 1-7. (2018)

[9]Gustari, I., Hadi, T. W., Hadi, S. and Renggono, F.: Akurasi prediksi curah hujan harian operasional di jabodetabek: perbandingan dengan model wrf. Jurnal Meteorologi dan Geofisika, pp. 119-130. (2012) 